\title{
Coexistence of non-functional ectopic thyroid tissue and a normal thyroid: A case report
}

\author{
WEI ZHENG ${ }^{1}$, JIAN TAN ${ }^{1}$ and TONG LIU ${ }^{2}$ \\ Departments of ${ }^{1}$ Nuclear Medicine and ${ }^{2}$ General Surgery, Tianjin Medical University General Hospital, \\ Heping, Tianjin 300052, P.R. China
}

Received April 10, 2013; Accepted July 22, 2013

DOI: $10.3892 /$ etm.2013.1244

\begin{abstract}
The aim of this study was to report a rare case of non-functional ectopic thyroid tissue in the neck with a coexisting normal thyroid. A 36-year-old female presented with a mass in the anterior neck. The thyroid function of the patient was normal. Ultrasonography and computed tomography (CT) revealed a normal thyroid gland and a solid mass in the middle lower neck. Scintigraphy showed a normal thyroid and the mass did show any uptake of ${ }^{99} \mathrm{mcO}_{4}$. The patient underwent en bloc resection. During surgery, the mass was observed to be well encapsulated and completely separated from the thyroid gland. Histology revealed it as ectopic thyroid tissue. The patient had an uneventful recovery.
\end{abstract}

\section{Introduction}

Ectopic thyroid tissue, defined as thyroid tissue not located anterior-laterally to the second and fourth tracheal cartilages, is rare. It is a congenital disease caused by the abnormal migration of thyroid tissue in the embryonic stage (1). In the majority of cases, ectopic thyroid is located in the midline, between the foramen caecum and the normal location of the thyroid gland, and most often it is located in the base of the tongue $(2,3)$. Patients usually present with symptoms, including a palpable but asymptomatic neck mass, dysphagia, dysphonia or dyspnea, according to the location and size of the mass. In the majority of cases, ectopic thyroid is the only thyroid tissue present (1). The current report describes a rare case: a 36-year-old female patient presented a non-functional ectopic thyroid tissue in the lower neck with a coexisting normal thyroid, which is infrequent in the clinic. The present study was approved by the ethics committee of Tianjin Medical University General Hospital (Tianjin, China) and adhered to the tenets of the Declaration of Helsinki. In addition, the written informed consent was obtained from the patient.

Correspondence to: Professor Jian Tan, Department of Nuclear Medicine, Tianjin Medical University General Hospital, 154 Anshan Road, Heping, Tianjin 300052, P.R. China

E-mail: zhengwe.ca@gmail.com

Key words: ectopic, thyroid, cervical mass, non-functional, histology

\section{Case report}

A 36-year-old female presented with a recent onset of a painless mass in the middle of the lower neck. The patient was asymptomatic and there was nothing significant in the medical history. Physical examination revealed a $\sim 4 \mathrm{~cm}$ immobile, non-tender mass in the patient's lower neck. Thyroid function tests, as well as the thyroglobulin ( $\mathrm{Tg}$ ) and thyroglobulin antibody ( $\mathrm{Tg} \mathrm{Ab})$ levels of the patient were normal: free triiodothyronine $\left(\mathrm{FT}_{3}\right)$, $4.65 \mathrm{pmol} / 1$ (normal range, 3.5-6.5 pmol/l); free thyroxine $\left(\mathrm{FT}_{4}\right)$, $18.52 \mathrm{pmol} / \mathrm{l}$ (normal range, 11.5-23.5 pmol/l); sensitive thyroid stimulating hormone (sTSH), $1.38 \mu \mathrm{IU} / \mathrm{ml}$ (normal range, $0.3-5.0 \mu \mathrm{IU} / \mathrm{ml}$ ); $\mathrm{Tg},<0.20 \mathrm{ng} / \mathrm{ml}$ (normal range, $0-55 \mathrm{ng} / \mathrm{ml}$ ); and $\mathrm{TgAb}, 26 \mathrm{IU} / \mathrm{ml}$ (normal range, $0-40 \mathrm{IU} / \mathrm{ml}$ ). Thyroid hormones and TSH were determined with an immunofluorometric assay. $\mathrm{Tg}$ and $\mathrm{TgAb}$ were measured with a radioimmunoassay. Blood serum calcitonin, calcium and parathyroid hormone (PTH) levels were normal. A neck ultrasound revealed a normal thyroid gland and a solid mass of heterogeneous echotexture in the middle lower cervical area, measuring $5.1 \times 2.8 \mathrm{~cm}$. The patient refused a fine needle aspiration (FNA) biopsy. A computed tomography (CT) scan of the neck revealed a well-defined mass below the thyroid gland, at the border of the cervical region and the thorax (Fig. 1). The mass suppressed the trachea; however, it was not causing narrowing of the trachea. ${ }^{99} \mathrm{mcO}_{4}{ }^{-}$scintigraphy of the patient's neck revealed only the normal thyroid gland; the cervical mass did not show any uptake of ${ }^{99} \mathrm{mcO}_{4}{ }^{-}$(Fig. 2).

The patient underwent en bloc resection, in which the cervical mass was identified as a separate structure from the thyroid gland. The patient had an uneventful postoperative recovery. Histological examination revealed that it showed large follicular cells of thyroid tissue distended with colloid material which confirms the characteristic of adenomatous hyperplasia (Fig. 3). Postoperatively the patient was euthyroid and had normal calcium levels.

\section{Discussion}

Ectopic thyroid tissue, defined as thyroid tissue not located anterior-laterally to the second and fourth tracheal cartilages, is rare. It was first described by Hickman in 1869 in a newborn baby who suffocated $16 \mathrm{~h}$ after birth due to a lingual thyroid causing upper airway obstruction $(4,5,6)$. It is a congenital disease caused by abnormal migration of thyroid tissue in the 


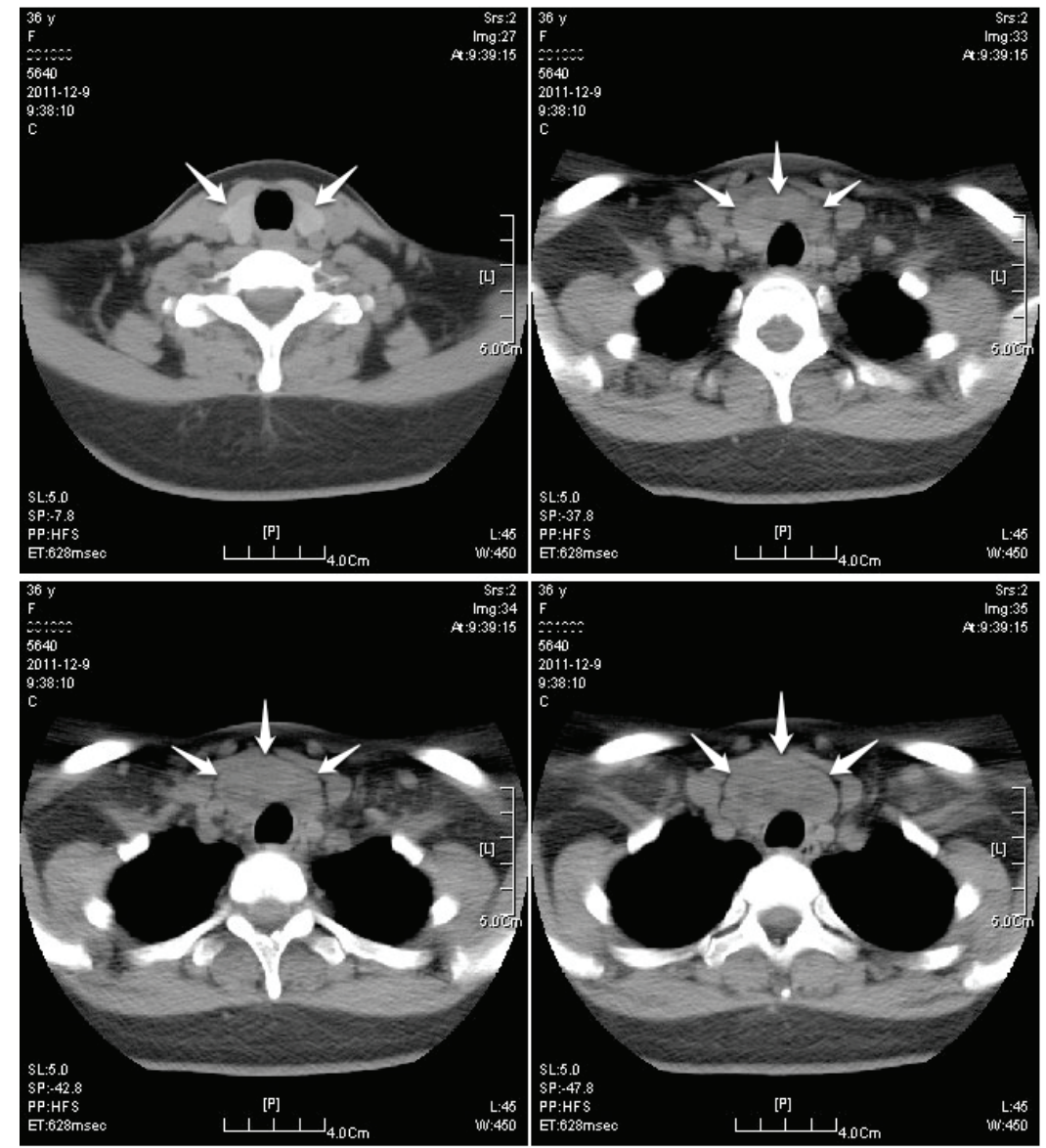

Figure 1. Computed tomography (CT) scans of the patient's neck revealed a well-defined mass below the thyroid gland on the border between the cervix and the thorax.

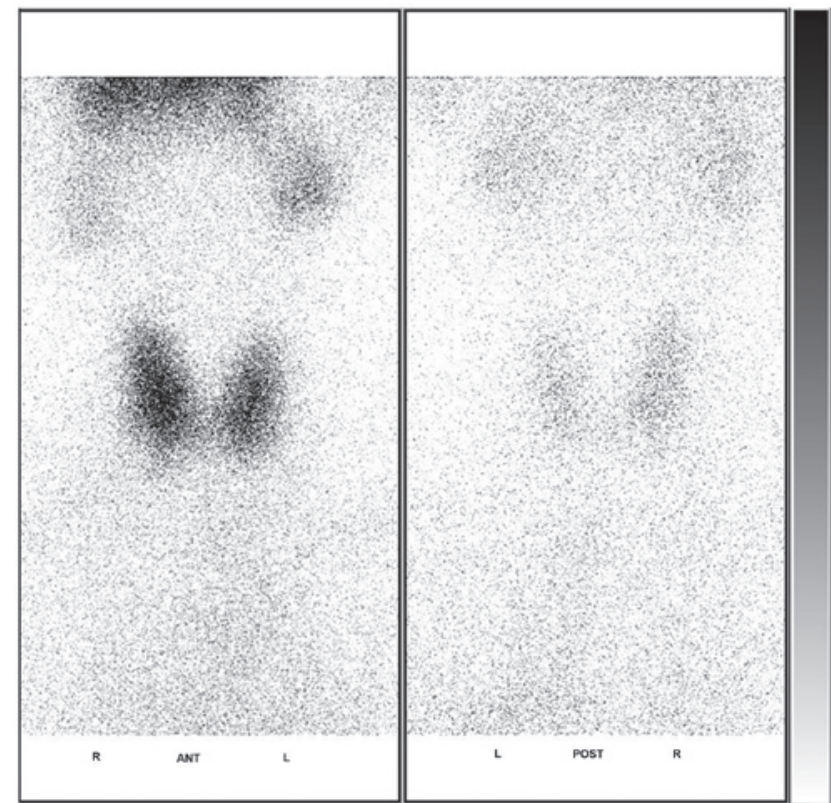

Figure 2. $\mathrm{In}^{99 \mathrm{~m}} \mathrm{TcO}_{4}{ }^{-}$scintigraphy of the patient's neck, only the normal thyroid gland was shown and the cervical mass did not take up the radionuclide.

embryonic stage. During embryogenesis, the descent of the thyroid does not proceed normally, leading to various possible anomalous locations of the gland. According to the timing
A

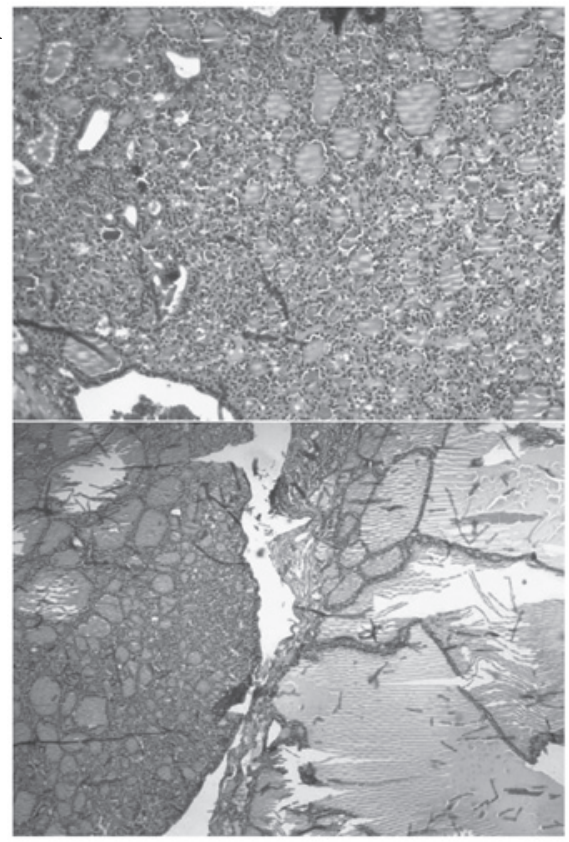

Figure 3. Histology revealed ectopic thyroid tissue with adenomatous nodules. (A) magnification, x100; (B) magnification, $\mathrm{x} 40$. The tissues were stained with hematoxylin and eosin.

of the embryonic development, thyroid descent may stop at various sites, from the base of the tongue to any site of the 
thyroglossal duct (3). In the majority of cases it is located in the midline, between the foramen caecum and the proper location of the thyroid gland, and most often it is located in the base of the tongue $(2,3)$. In the current study, a rare case of a non-functioning ectopic thyroid in the lower cervical area in a female patient with a normal thyroid gland is presented.

Lingual thyroid is the most common form of ectopic thyroid (7), which may cause dysphonia (8). Extralingual thyroid tissue is commonly located in the anterior cervical area, along the path of the thyroglossal duct (3). In the patient in the present study it was located underneath the thyroid in the lower neck, which is a rare location. Other rare locations of ectopic thyroid include the submandibular region (9), parotid salivary gland (10), trachea (11), lateral to the carotid arteries and jugular veins (7), mediastinum (12), heart (13), lung (14), duodenum (15), adrenal gland (16) and uterus (17).

The exact incidence of ectopic thyroid is unknown. Post-mortem studies suggest that asymptomatic thyroid tissue may be located along the path of the thyroglossal duct in as many as $7-10 \%$ of adults (18). Ectopic thyroid tissue may be the only functioning tissue $(3,19,20)$ or may coexist with a normal thyroid gland $(9,21,22)$, as in the present case.

Radionuclide imaging ( $\mathrm{RI}$ ) is considered the definitive diagnostic test method for detecting ectopic thyroid tissue. In the present case, no uptake of radiotracer was observed in the ectopic thyroid. In a previous study, the findings on color Doppler ultrasonography (CDU), gray-scale ultrasonography (GSU) and magnetic resonance imaging (MRI) were compared with those of RI and the sensitivities for detecting ectopic thyroid were calculated (23). In the patients with ectopic thyroid, the sensitivity of CDU, GSU and MRI for detecting ectopic thyroid was 90,70 and $70 \%$, respectively. CDU is superior to GSU and MRI for detecting ectopic thyroid.

Ectopic thyroid tissue may undergo the same pathological changes as the eutopic thyroid gland, including thyrotoxicosis $(19)$, and may be benign or malignant $(11,12,24)$. Malignant transformation of ectopic thyroid tissue is extremely uncommon. If, however, thyroid tissue is located in the lateral cervical lymph nodes, metastasis of a malignant thyroid tumor should be excluded (25).

Ectopic thyroid tissue poses difficult diagnostic and management challenges. The treatment of ectopic thyroid tissue depends on factors such as mass size, local symptoms, the age of the patient, the functional status of the thyroid gland and complications, including ulceration, hemorrhage and neoplasia $(26,27)$. In order to prevent misdiagnosis and mismanagement, patients with a cervical mass in the anterior midline should be subjected to history screening, physical examination, cervical CDU, RI, thyroid function examinations (TSH, $\mathrm{FT}_{3}$ and $\mathrm{FT}_{4}$ ), FNA biopsy and histological examinations during surgery (23).

\section{References}

1. Noussios G, Anagnostis P, Goulis DG, Lappas D and Natsis K Ectopic thyroid tissue: anatomical, clinical, and surgical implications of a rare entity. Eur J Endocrinol 165: 375-382, 2011.

2. Damiano A, Glickman AB, Rubin JS and Cohen AF: Ectopic thyroid tissue presenting as a midline neck mass. Int J Pediatr Otorhinolaryngol 34: 141-148, 1996.
3. Larochelle D, Arcand P, Belzile M and Gagnon NB: Ectopic thyroid tissue - a review of the literature. J Otolaryngol 8: $523-530,1979$

4. Kumar Choudhury B, Kaimal Saikia U, Sarma D, et al: Dual ectopic thyroid with normally located thyroid: a case report. J Thyroid Res 2011: 159703, 2011.

5. Bersaneti JA, Silva RD, Ramos RR, Matsushita Mde M and Souto LR: Ectopic thyroid presenting as a submandibular mass. Head Neck Pathol 5: 63-66, 2011.

6. Kumar Choudhury B, Kaimal Saikia U, Sarma D, et al: Dual ectopic thyroid with normally located thyroid: a case report. J Thyroid Res 2011: 159703, 2011.

7. Batsakis JG, El-Naggar AK and Luna MA: Thyroid gland ectopias. Ann Otol Rhinol Laryngol 105: 996-1000, 1996.

8. Stoppa-Vaucher S, Lapointe A, Turpin S, Rydlewski C, Vassart G and Deladoëy J: Ectopic thyroid gland causing dysphonia: imaging and molecular studies. J Clin Endocrinol Metab 95: 4509-4510, 2010

9. Feller KU, Mavros A and Gaertner HJ: Ectopic submandibular thyroid tissue with a coexisting active and normally located thyroid gland: case report and review of literature. Oral Surg Oral Med Oral Pathol Oral Radiol Endod 90: 618-623, 2000.

10. Mysorekar VV, Dandekar CP and Sreevathsa MR: Ectopic thyroid tissue in the parotid salivary gland. Singapore Med J 45: 437-438, 2004.

11. Hari CK, Brown MJ and Thompson I: Tall cell variant of papillary carcinoma arising from ectopic thyroid tissue in the trachea. J Laryngol Otol 113: 183-185, 1999.

12. Sand J, Pehkonen E, Mattila J, Seppănen S and Salmi J: Pulsating mass at the sternum: a primary carcinoma of ectopic mediastinal thyroid. J Thorac Cardiovasc Surg 112: 833-835, 1996.

13. Casanova JB, Daly RC, Edwards BS, Tazelaar HD and Thompson GB: Intracardiac ectopic thyroid. Ann Thorac Surg 70: 1694-1696, 2000.

14. Bando T, Genka K, Ishikawa K, Kuniyoshi M and Kuda T: Ectopic intrapulmonary thyroid. Chest 103: 1278-1279, 1993.

15. Takahashi $\mathrm{T}$, Ishikura $\mathrm{H}$, Kato $\mathrm{H}$, Tanabe $\mathrm{T}$ and Yoshiki $\mathrm{T}$ : Ectopic thyroid follicles in the submucosa of the duodenum. Virchows Arch A Pathol Anat Histopathol 418: 547-550, 1991.

16. Shiraishi T, Imai H, Fukutome $K$, Watanabe $M$ and Yatani R: Ectopic thyroid in the adrenal gland. Hum Pathol 30: 105-108, 1999.

17. Yilmaz F, Uzunlar AK and Sögütçü N: Ectopic thyroid tissue in the uterus. Acta Obstet Gynecol Scand 84: 201-202, 2005.

18. Sauk JJ Jr: Ectopic lingual thyroid. J Pathol 102: 239-243, 1970.

19. Kumar R, Gupta R, Bal CS, Khullar S and Malhotra A: Thyrotoxicosis in a patient with submandibular thyroid. Thyroid 10: 363-365, 2000.

20. Aguirre A, de la Piedra M, Ruiz R and Portilla J: Ectopic thyroid tissue in the submandibular region. Oral Surg Oral Med Oral Pathol 71: 73-76, 1991.

21. Richards PS, Ahuja AT and King AD: Clinics in diagnostic imaging (101): multinodular accessory thyroid tissue. Singapore Med J 45: 542-546, 2004.

22. Mace AT, McLaughlin I, Gibson IW and Clark LJ: Benign ectopic submandibular thyroid with a normotopic multinodular goitre. J Laryngol Otol 117: 739-740, 2003.

23. Ohnishi $H$, Sato $H$, Noda $H$, Inomata $H$ and Sasaki N: Color Doppler ultrasonography: diagnosis of ectopic thyroid gland in patients with congenital hypothyroidism caused by thyroid dysgenesis. J Clin Endocrinol Metab 88: 5145-5149, 2003.

24. Ling L, Zhou SH, Wang SQ and Wang LJ: Misdiagnosed ectopic thyroid carcinoma: report of two cases. Chin Med J (Engl) 117: $1588-1589,2004$.

25. Kousta E, Konstantinidis K, Michalakis C, et al: Ectopic thyroid tissue in the lower neck with a coexisting normally located multinodular goiter and brief literature review. Hormones (Athens) 4: 231-234, 2005.

26. Nasiru Akanmu I and Mobolaji Adewale O: Lateral cervical ectopic thyroid masses with eutopic multinodular goiter: an unusual presentation. Hormones (Athens) 8: 150-153, 2009.

27. Abellán Galiana P, Cámara Gómez R, Campos Alborg V, Rivas Sánchez A, Salom Fuster JV and Muñoz Gómez C: Dual ectopic thyroid: subclinical hypothyroidism after extirpation of a submaxillary mass. Rev Esp Med Nucl 28: 26-29, 2009 (In Spanish). 